\title{
Degradation of phytic acid from tithonia (Tithonia diversifolia) leaves using Lactobacillus bulgaricus at different fermentation times
}

\author{
RONI PAZLA ${ }^{1, \boldsymbol{v}}$, GUSRI YANTI ${ }^{1}$, NOVIRMAN JAMARUN ${ }^{1}$, ARIEF $^{2}$, ELIHASRIDAS $^{\mathbf{1}}$, \\ LARAS SUKMA SUCITRA \\ ${ }^{1}$ Department of Nutrition Science and Feed Technology, Faculty of Animal Husbandry, Universitas Andalas. Jl. Kampus, Limau Manis, Padang 25163, \\ West Sumatra, Indonesia. Tel./fax.: +62-751-71464, `email: ronipazla @ansci.unand.ac.id \\ ${ }^{2}$ Department of Technology and Animal Production, Faculty of Animal Husbandry, Universitas Andalas. Jl. Kampus, Limau Manis, Padang 25163, West \\ Sumatra, Indonesia
}

Manuscript received: 31 August 2021. Revision accepted: 14 October 2021.

\begin{abstract}
Pazla R, Yanti G, Jamarun N, Arief, Elihasridas, Sucitra LS. 2021. Degradation of phytic acid from tithonia (Tithonia diversifolia) leaves using Lactobacillus bulgaricus at different fermentation times. Biodiversitas 22: 4794-4798. The aim of this study is to reduce high level of phytic acid in tithonia (Tithonia diversifolia) leaves by fermentation technique using Lactobacillus bulgaricus. A completely randomized design consisting of four treatments (fermentation time) i.e. T2: 2 days, T3: 3 days, T4: 4 days and T5: 5 days and experiment was performed in four replicates. The parameters measured were $\mathrm{pH}$, phytase enzyme activity, total bacterial colony, phytic acid content, and phytic acid degradation. The results showed that the fermentation time had a significant effect $(\mathrm{P}<0.05)$ on $\mathrm{pH}$, phytase enzyme activity, total bacterial colony, phytic acid content, and phytic acid degradation. The conclusion of this study is that on fifth day (Treatment T5) fermented tithonia leaves produced the lowest levels of phytic acid (3.48 mg/ $100 \mathrm{~g})$ with the highest level of degradation $(64.81 \%)$.
\end{abstract}

Keywords: Fermentation times, Lactobacillus bulgaricus, phytic acid, ruminant feed, Tithonia diversifolia.

\section{INTRODUCTION}

Tithonia diversifolia (Hamsley) A.Gray is a forage protein source for ruminants has been studied by researchers. Pazla (2018) reported that the leaves and stem of tithonia plant contain $84.01 \%$ organic matter, $22.98 \%$ crude protein, $18.17 \%$ crude fiber and $34.59 \%$ cellulose. Tithonia leaves are rich in essential amino acids, such as methionine, leucine, isoleucine, and valine which are important for the growth of rumen microbes (Oluwasola and Dairo 2016). Tithonia leaves contain macro minerals, such as $\mathrm{Ca}$ and $\mathrm{Mg}$ and several micro-minerals that are very beneficial for rumen microbial activity and growth (Mahecha and Rosales 2005).

Besides containing good nutritional potential, tithonia also contains many anti-nutritional substances, which are harmful to livestock health (Aye 2016; Jamarun et al. 2020). Phytic acid is the most anti-nutritional substance in tithonia (Fasuyi et al. 2010). Phytic acid $\left(\mathrm{C}_{6} \mathrm{H}_{18} \mathrm{O}_{24} \mathrm{P}_{6}\right.$ or IP6) is a phosphate-bound myo-inositol ring (Turk 1990; Susanti 2012). The high level of phytic acid in tithonia produces a bitter taste, which diminishes the flavor of plant, causing the animal to consume less of it (Pazla et al. 2021a). Phytic acid has also been reported to bind proteins, carbohydrates and minerals essential for rumen microbes such as P, Mg and Zn (Lai et al. 2013; Selle et al. 2021). Feeds containing high phytic acid have a fast rate of degradation ( $<8$ hours) in the rumen, leading to limited phytic acid degradation by rumen microbes and a greater chance of feed phytic acid escaping to post-rumen. This condition negatively affects because phytic acid as a chelating agent can bind some minerals or compounds essential to ruminants. Rumen microbes produce many phytase enzymes, but very few enzymes are present in the post-rumen. It is difficult to break down phytic acid into free inositol and phosphate (Park et al. 1999). Nonruminant livestock, such as pigs and chickens do not have phytase enzymes, so they cannot degrade phytic acid to digestible phosphorus (Greiner and Konietzny 2011). Phytic acid content in pig feed is usually between 7 and 10 $\mathrm{g} / \mathrm{kg}$ of diet (Selle et al. 2009).

The phosphorus in phytic acid is difficult to digest. This causes phosphorus cannot be utilized by rumen microbes and livestock bodies. The phosphorus will be wasted through feces and pollute the environment. The body can use elemental $\mathrm{P}$ in the degradation of phytic acid. Degradation is the process of breaking the bonds of myoinositol group with the phosphate group. The released phosphate is a source of phosphorus for the body and rumen microbes (Pazla et al. 2018, 2020).

Fermentation technology can be used to degrade phytic acid. Lactobacillus bulgaricus which produces phytase enzymes used as a phytate-degrading microorganism (Mohamed et al. 2011; Sripo et al. 2016). The aim of this study is to reduce the high level of phytic acid content in tithonia (T. diversifolia) leaves using $L$. bulgaricus at different fermentation times. 


\section{MATERIALS AND METHODS}

\section{Experimental site}

Lactobacillus bulgaricus culture was collected from the Livestock Technology Laboratory, Faculty of Animal Husbandry, Bogor Agricultural University, Indonesia. Tithonia leaves were taken from Padang Panjang, West Sumatra, Indonesia. The fermentation process was carried out in the Technology and Feed Industry Laboratory, Faculty of Animal Husbandry, Andalas University, Indonesia.

\section{Procedures}

Rejuvenation of Lactobacillus bulgaricus

Lactobacillus bulgaricus was grown on Potato Dextrose Agar (PDA) media. $4.04 \mathrm{~g}$ of PDA media was dissolved with $175 \mathrm{~mL}$ of distilled water in an Erlenmeyer flask, and then heated on a hot plate until boiling. The flask was covered with cotton plug and sealed with aluminum foil, then sterilized in autoclave for 30 minutes at $121^{\circ} \mathrm{C}$. After cooling, media was inoculated with $5 \mathrm{~mL}$ of $L$. bulgaricus and incubated in a shaker incubator at $37^{\circ} \mathrm{C}$ for 48 hours.

\section{Tithonia fermentation process}

A $50 \mathrm{~g}$ of tithonia flour was mixed with $80 \mathrm{~mL}$ of distilled water and put in a plastic bag, then homogenized. Then plastic bags were sterilized in an autoclave at $121^{\circ} \mathrm{C}$ for 30 minutes and cool down. After that, $1.5 \mathrm{~mL}$ of $L$. bulgaricus was inoculated into broodstock and homogenized. All samples were tightly covered with tape and plastic wrap and stored at room temperature for further investigation. Fermentation was done for four days i.e. T2: 2 days, T3: 3 days, T4: 4 days and T5: 5 days.

\section{Total bacterial colonies}

Weighed $10 \mathrm{~g}$ of the fermented sample, dissolved in 90 $\mathrm{mL}$ of distilled water $\left(10^{1}\right)$. Prepared 8 test tubes (containing $9 \mathrm{~mL}$ of distilled water). Pipette $1 \mathrm{~mL}$ of broodstock liquor $\left(10^{1}\right)$, transferred to test tube $10^{2}$ and then homogenized, continued until $10^{9}$ dilution. Next, pipette $1 \mathrm{~mL}$ of solution from test tube $8\left(10^{9}\right)$ transferred into a petri dish. Add $10 \mathrm{~mL}$ of MRS Agar (De man Rogosa and Sharpe) medium, homogenize. Incubated at $37^{\circ} \mathrm{C}$ for 24 hours. Count the total bacterial colonies.

\section{Making phytase media}

The purpose of making phytase media was to measure the activity of phytase enzyme. For this $1.5 \mathrm{~g}$ of glucose, $1.5 \mathrm{~g}$ of MRS Agar, $0.05 \mathrm{~g}$ of $\mathrm{MgSO}_{4}, 0.02 \mathrm{~g}$ of $\mathrm{MnSO}_{4}$, $0.05 \mathrm{~g}$ of $\mathrm{KCl}, 0.5 \mathrm{~g}$ of Ca-Phytate, $0.5 \mathrm{~g}$ of $\mathrm{NH}_{4} \mathrm{NO}_{3}$ and $0.001 \mathrm{~g}$ of $\mathrm{FeSO}_{4}$ was put in a flask and added $100 \mathrm{~mL}$ of distilled water. Then boil it on a hot plate, cover with aluminum foil and sterilized at $121^{\circ} \mathrm{C}$ for 30 minutes in autoclave. Media was poured into a sterilized petri dish and inoculated by spread with $1 \mathrm{~mL}$ of $L$. bulgaricus broodstock. The plates were then tightly covered with plastic wrap and stored at room temperature for 24 hours.

\section{Measurement of phytic acid content}

One gram of sample was homogenized with $50 \mathrm{~mL}$ of $0.5 \mathrm{M} \mathrm{HNO}_{3}$ using a shaker for 2 hours, then strained. The filtrate was used for the measurement of phytic acid. 0.9 $\mathrm{mL}$ of $0.5 \mathrm{~N} \mathrm{HNO}_{3}$, and $1 \mathrm{~mL}$ of $\mathrm{FeCl}_{3}$ (containing iron ions 50 micrograms $/ \mathrm{mL}$ ) were added to $0.5 \mathrm{~mL}$ of filtrate, covered with aluminum foil, and then kept in boiling water for 20 minutes. Cool the tubes with water, adding $5 \mathrm{~mL}$ of amyl alcohol and $1 \mathrm{~mL}$ ammonium thiocyanate (10\%). Tubes were centrifuged for 10 minutes at $10,000 \mathrm{rpm}$ and absorbance was measured at $465 \mathrm{~nm}$ using spectrophotometry.

\section{Measurement of phytase enzyme activity}

A $0.15 \mathrm{~mL}$ of enzyme was taken in a test tube, then 0.6 $\mathrm{mL}$ of $0.1 \mathrm{M}$ Tris $\mathrm{HCl}$ buffer containing Ca-phytate, $\mathrm{CaCl}$ 2, 0.75 TCA $5 \%$ was added and incubated at $37^{\circ} \mathrm{C}$ for 30 min. After that, $1.5 \mathrm{~mL}$ molybdate color reagent was added and homogenized by vortex. Absorbance of the characteristic color was measured at $700 \mathrm{~nm}$ against blank using spectrophotometer.

\section{Data analysis}

Data were statistically analyzed by analysis of variance with four treatments (fermentation time) and four repetitions using SPSS software version 20.0. Differences between treatments means were determined by Duncan's Multiple Range Test. The level of statistical significance was set at $\mathrm{p}<0.05$.

\section{RESULTS AND DISCUSSION}

\section{Total bacterial colonies}

The statistical analysis results showed that the treatment had a significantly different effect $(\mathrm{P}<0.05)$ on the total bacterial colonies. Based on Table 1, the average entire bacteria colony ranged from $8.50-31 \times 10^{9} \mathrm{U} / \mathrm{mL}$. $\quad L$. bulgaricus has four growth phases: the lag phase, exponential phase, stationary phase, and death phase (Malaka 1997). L. bulgaricus reached its optimum growth on second day of fermentation with a total bacterial colony of $31 \times 10^{9} \mathrm{U} / \mathrm{mL}$. Bacterial growth was decreased by the 5 th day of fermentation with whole colony of $8.5 \times 10^{9}$ $\mathrm{U} / \mathrm{mL}$. The lag phase of $L$. bulgaricus occurred on 24 hours of incubation. After that, the bacteria entered an exponential phase and with the maximum number of colonies appeared on second day. There was a sharp decrease in total bacterial colonies on the third day. This may be due to decreased nutrient levels and accumulation of toxic products that interfere with bacterial cell division. Bacterial death rate was more significant on the 5th day of incubation, leading to a reduction in bacterial population. The total bacterial colony in this study was higher than the results of Malaka and Laga (2005) research, which was 4.9 $\times 10^{9}$, and lower than the Sripo et al. (2016) study, which was $7 \times 10^{10} \mathrm{U} / \mathrm{mL}$. The difference is caused by the type of substrate and the length of fermentation. The total colonies of $L$. bulgaricus bacteria at different fermentation times can be seen in Figure 1. 


\section{Phytase enzyme activity}

Table 1 showed that the length of fermentation had a significant effect $(\mathrm{P}<0.05)$ on phytase enzyme activity. The highest i.e. $15.02 \mathrm{U} / \mathrm{mL}$ phytase enzyme activity occurred on second day of fermentation (T2 treatment) and decreased with the length of fermentation time. The lowest i.e. $5.06 \mathrm{U} / \mathrm{mL}$ phytase enzyme activity was recorded on fifth day (T5). The optimal movement of phytase enzyme on second day of fermentation (T2) was due to the high nutrient content of the substrate for the growth of $L$. bulgaricus. The total number of bacterial colonies reached an optimum growth of $31 \times 10^{9} \mathrm{U} / \mathrm{mL}$ on the second day of fermentation. Bacterial populations can result in high enzyme activity. Enzyme activity is strongly influenced by the nutrient content of the substrate (Poernomo et al. 2017; Pazla et al. 2020).

The longer the fermentation time, the lower the nutrient content of the substrate as bacteria use up all the food for their activity and growth. Putra et al. (2019) stated that the fermentation process carried out by microorganisms can remodel carbohydrates into alcohol, organic acids, $\mathrm{H}_{2} \mathrm{O}$, and $\mathrm{CO}_{2}$. Also, Mirnawati et al. (2013) added that the length of fermentation time depletes the nutrients in the substrate as the microorganisms utilized it for their growth. Phytase enzymes produced during the fermentation process contribute significantly to the level of phytic acid substrates. The higher the activity of phytase enzyme produced by microbes, the lower the phytic acid content (Reddy and Pierson 1994). In this study, phytase enzyme activity from L. bulgaricus was higher, but the activity of phytase enzyme produced by Lactobacillus plantarum in the fermented tithonia plant was 6.68-11.71 U/mL (Pazla et al. 2021b). The difference in values may be due to the type of lactic acid bacteria used. The phytase enzyme activity of $L$. bulgaricus bacteria at different fermentation times can be seen in Figure 2.

\section{Phytic acid content and phytic acid degradation}

Statistical analysis showed that the treatment duration of fermentation had a significantly different effect $(\mathrm{P}<0.05)$ on phytic acid content and phytic acid degradation (Table 1 and Table 2). The T2 treatment (2 days of fermentation) showed highest phytic acid content of $4.85 \mathrm{mg} / 100 \mathrm{~g}$ with a degradation rate of $51.03 \%$. The lowest $(3.48 \mathrm{mg} / 100 \mathrm{~g})$ phytic acid content was observed on fifth day of fermentation (T5), with a degradation rate of $64.81 \%$. Phytic acid content decreased with increasing fermentation time. This is due to the phytase enzyme produced by $L$. bulgaricus bacteria during the fermentation process. Table 1 showed that L. bulgaricus carried phytase enzyme activity by the fifth day of fermentation. Phytase (myoinositol-hexakisphosphate-3-phosphohydrolase) is an enzyme that catalyzes myo-inositol hexakisphosphate (phytate) to inorganic orthophosphate and a lower series of phosphoric (inositol Penta phosphate to monophosphate) and finally to free Myo-inositol (Selle and Ravindran 2007). Phytase can release phosphorus bound to phytate to be available and can be utilized by livestock (Hidayat 2016). The duration of fermentation results in the accumulation of phytate degradation by L. bulgaricus bacteria which leads to a decrease in phytate content on the fifth day of fermentation. In this study, phytic acid degradation was higher than Sripo et al. (2016) research, $54.8 \%$ in fermented black glutinous rice and lower than the results of Mohamed et al. (2011) study, which was $69.2 \%$ in fermented mung bean using L. bulgaricus. These differences in results may be due to the different types of substrates. The phytic acid content of fermented tithonia leaves by $L$. bulgaricus bacteria at different fermentation times can be seen in Figure 3.

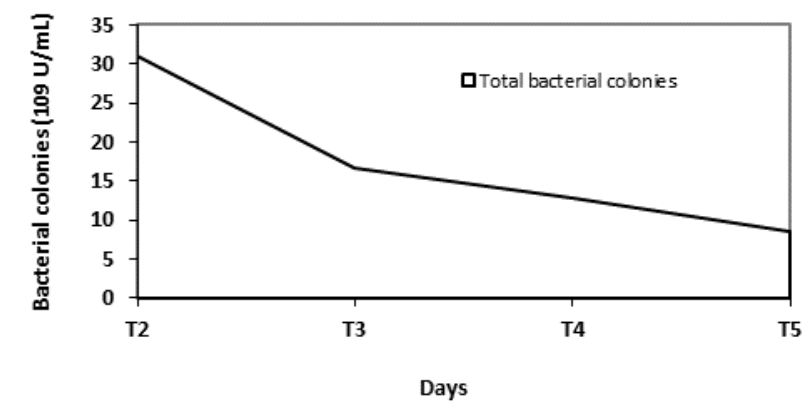

Figure 1. Total bacterial colonies of fermented tithonia leave by Lactobacillus bulgaricus at different fermentation times. * T2 (2 days), T3 (3 days), T4 (4 days) and T5 (5days)

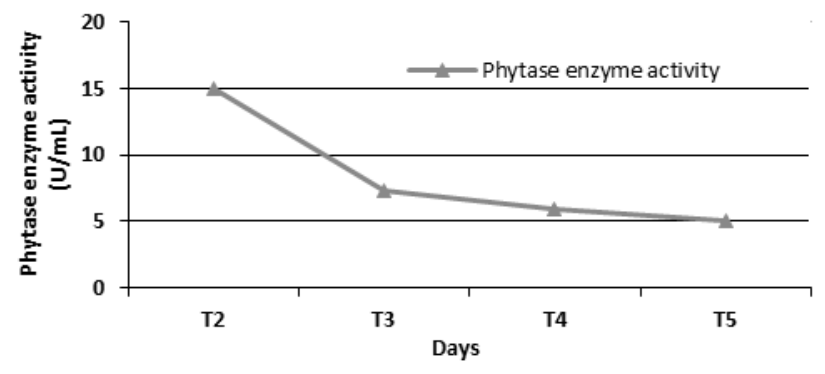

Figure 2. Phytase enzyme activity of fermented tithonia leaves by Lactobacillus bulgaricus at different fermentation times. * T2 (2 days), T3 (3 days), T4 (4 days) and T5 (5days)

Table 1. Total bacterial colonies, phytase enzyme activity, phytic acid content and $\mathrm{pH}$ of fermented tithonia leaves by Lactobacillus bulgaricus at different fermentation times

\begin{tabular}{|c|c|c|c|c|c|}
\hline \multirow{2}{*}{ Parameters } & \multicolumn{4}{|c|}{ Treatments } & \multirow[b]{2}{*}{ SEM } \\
\hline & $* \mathbf{T 2}$ & T3 & T4 & T5 & \\
\hline Total bacterial colonies $\left(10^{9}\right)$ & $31^{\mathrm{d}} \pm 5.48$ & $16.75^{\mathrm{c}} \pm 2.22$ & $12.75^{\mathrm{b}} \pm 2.22$ & $8.5^{\mathrm{a}} \pm 1.29$ & 0.81 \\
\hline Phytase enzyme activity (U/mL) & $15.02^{\mathrm{d}} \pm 0.26$ & $7.32^{c} \pm 0.35$ & $5.94^{\mathrm{b}} \pm 0.18$ & $5.06^{\mathrm{a}} \pm 0.25$ & 0.07 \\
\hline phytic acid content $(\mathrm{mg} / 100 \mathrm{~g})$ & $4.85^{\mathrm{d}} \pm 0.17$ & $3.99^{\mathrm{bc}} \pm 0.18$ & $3.89^{\mathrm{b}} \pm 0.13$ & $3.48^{\mathrm{a}} \pm 0.34$ & 0.05 \\
\hline $\mathrm{pH}$ & $6.97^{\mathrm{c}} \pm 0.06$ & $6.98^{c} \pm 0.04$ & $7.09^{\mathrm{a}} \pm 0.02$ & $7.29^{\mathrm{ab}} \pm 0.09$ & 0.02 \\
\hline
\end{tabular}

Note: Different superscripts (a,b,c,d) in the same row are significantly different $(\mathrm{P}<0.05) . *$ T2: 2 days, T3: 3 days, T4: 4 days and T5: 5days 


\section{pH fermentation}

$\mathrm{pH}$ is an acid-base condition of the fermentation medium associated with the growth activity of microorganisms. The rate of microbial cell death can be triggered when the $\mathrm{pH}$ is too low (acidic) or too high (alkaline). The high mortality rate of microorganisms affects the speed of fermentation. The range of $\mathrm{pH}$ values obtained was 6.97-7.29. This $\mathrm{pH}$ value supported the growth of $L$. bulgaricus. The optimum $\mathrm{pH}$ for the development of L. bulgaricus is 5.5-6.2, and the growth rate decreases in the early alkaline media (Sneath et al. 1986). Malaka and Laga (2005) reported that L. bulgaricus could grow at alkaline $\mathrm{pH}(8.1)$.

Table 2. Phytic acid degradation of fermented tithonia leaves by Lactobacillus bulgaricus at different fermentation times

\begin{tabular}{|c|c|c|c|}
\hline \multirow[b]{2}{*}{ Treatments } & \multicolumn{2}{|c|}{ Phytic acid content $(\mathrm{mg} / 100 \mathrm{~g})$} & \multirow{2}{*}{$\begin{array}{c}\text { Phytic acid } \\
\text { degradation } \\
(\%)\end{array}$} \\
\hline & $\begin{array}{c}\text { Before } \\
\text { fermentation }\end{array}$ & $\begin{array}{c}\text { After } \\
\text { fermentation }\end{array}$ & \\
\hline *T2 & $9.93 \pm 0.58$ & $4.85 \pm 0.17$ & $51.03^{\mathrm{a}} \pm 4.26$ \\
\hline T3 & $9.93 \pm 0.58$ & $3.99 \pm 0.18$ & $59.74^{\mathrm{b}} \pm 3.10$ \\
\hline $\mathrm{T} 4$ & $9.93 \pm 0.58$ & $3.89 \pm 0.13$ & $60.83^{\mathrm{bc}} \pm 1.05$ \\
\hline T5 & $9.93 \pm 0.58$ & $3.48 \pm 0.34$ & $64.81^{\mathrm{c}} \pm 4.58$ \\
\hline SEM & & & 0.88 \\
\hline
\end{tabular}

Note: Different superscripts (a, b, c, d) in the same column are significantly different $(\mathrm{P}<0.05) .{ }^{*} \mathrm{~T} 2: 2$ days, T3: 3 days, T4: 4 days and T5: 5days

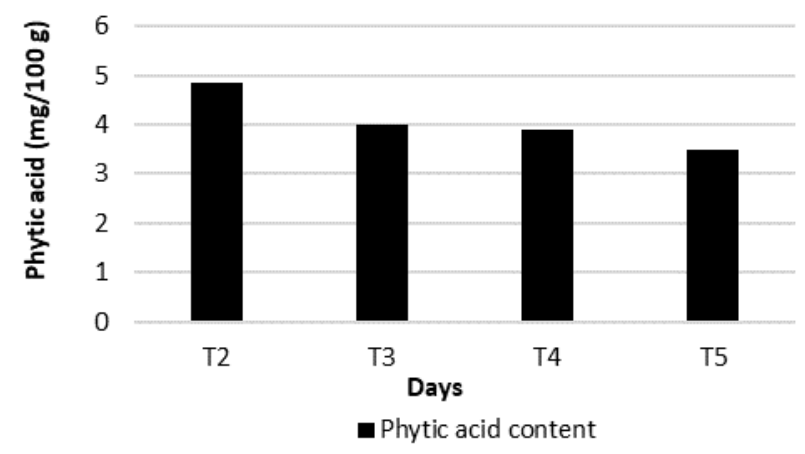

Figure 3. The phytic acid content of fermented tithonia leaves by L. bulgaricus at different fermentation times. * T2 (2 days), T3 (3 days), T4 (4 days) and T5 (5days)

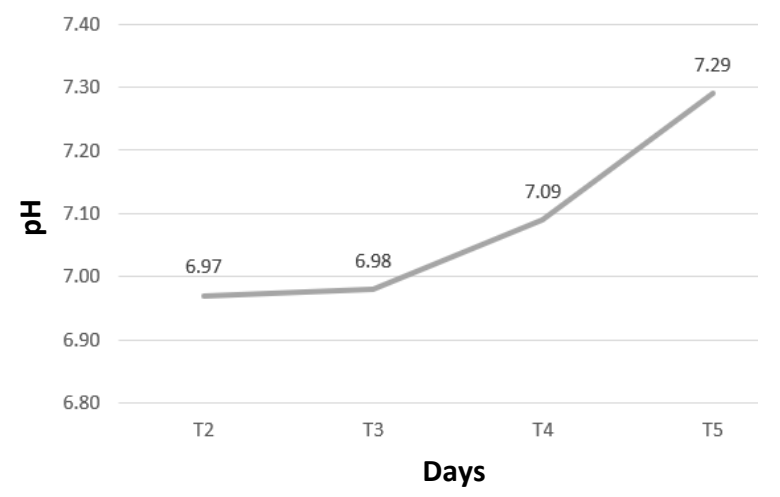

Figure 4. $\mathrm{pH}$ of fermented tithonia leaves by Lactobacillus bulgaricus at different fermentation times. * T2 (2 days), T3 (3 days), T4 (4 days) and T5 (5days)
Statistical analysis showed that fermentation time had a significant effect $(\mathrm{P}<0.05)$ on $\mathrm{pH}$. The lowest $\mathrm{pH}$ value was found in $\mathrm{T} 2$ treatment, i.e. two days of fermentation. The $\mathrm{pH}$ value continued to increase till the fifth day of fermentation i.e. 7.29. An increase in $\mathrm{pH}$ from 2 nd day to the 5th day of fermentation indicates that the fermentation process is well underway. The $\mathrm{pH}$ can encourage the optimum activity of bacterial microorganisms. The degree of acidity at the beginning of fermentation process converts organic matter into organic acids, besides the reshuffle of phytic acid by the phytase enzyme that occurs during the fermentation process, phytic acid is hydrolyzed into inositol, thereby increasing the $\mathrm{pH}$ (Mittal et al. 2011). In addition, Sneath et al. (1986) reported that the $L$. bulgaricus also reduced nitrate, causing an increase in the $\mathrm{pH}$ value of fermentation towards alkaline. Also, Hati (2018) states that the increase in $\mathrm{pH}$ in the fermentation process towards neutral occurs due to microorganisms that convert organic acids. The $\mathrm{pH}$ of fermented tithonia by $L$. bulgaricus at different fermentation times can be seen in Figure 4. From the results above, it can be concluded that tithonia leaves fermented with L. bulgaricus on fifth day showed the lowest phytic acid content $3.48 \mathrm{mg} / 100 \mathrm{~g}$ with phytic acid degradation of $64.81 \%$.

\section{ACKNOWLEDGEMENTS}

The authors would like to thank the research and community service institute Andalas University, Indonesia who has funded this research with the contract number: T/19/UN.16.17/PT.01.03/Pangan-RPB/2021 and also the technicians of the technology and feed industry laboratory technicians, Faculty of Animal Husbandry, Andalas University and laboratory technicians from livestock products technology, Faculty of Animal Husbandry, Bogor Agricultural University, Indonesia.

\section{REFERENCES}

Aye PA. 2016. Comparative nutritive value of Moringa oleifera, Tithonia diversifolia and Gmelina arborea leaf meals. Amer J Food Nutr 6 (1): 23-32.

Fasuyi AO, Dairo FAS, Ibitayo FJ. 2010. Ensiling wild sunflower (Tithonia diversifolia) leaves with sugar cane molasses. Lives Res Rural Dev 22: 42. http://www.lrrd.org/lrrd22/3/fasu22042.htm [1810-2020].

Greiner R, Konietzny U. 2011. Phytase: biochemistry, enzymology and characteristics relevant to animal feed use. In: Bedford MR, Partridge GG (eds.). Enzymes in Farm Animal Nurition 2nd ed. AB Vista Feed Ingredients Ltd., UK. DOI: 10.1079/9781845936747.0096.

Hati S. 2018. Pembuatan Pupuk Kompos Cair dari Limbah Rumah Tangga sebagai Penunjang Mata Kuliah Ekologi dan Masalah Lingkungan. [Thesis]. Islam Negeri Ar-Raniry Darussalam University, Banda Aceh. [Indonesian]

Hidayat C. 2016. Utilisation of phytase to overcome phytic acid in broiler diet. Wartazoa 26 (2): 57-68. DOI: 10.14334/wartazoa.v26i2.1326.

Jamarun N, Pazla R, Arief, Jayanegara A, Yanti G. 2020. Chemical composition and rumen fermentation profile of mangrove leaves (Avicennia marina) from West Sumatra, Indonesia. Biodiversitas 21 (11): 5230-5236. DOI: 10.13057/biodiv/d211126.

Lai LR, Hsieh SC, Huang HY, Chou C. 2013. Effect of lactic fermentation on the total phenolic, saponin and phytic acid contents as well as anti- 
colon cancer cell proliferation activity of soymilk. J Biosci Bioeng 115 (5): 552-556. DOI: 10.1016/j.jbiosc.2012.11.022.

Mahecha L, Rosales M. 2005. Nutritional value of the foliage of wild sunflower (Botón de Oro; (Tithonia diversifolia [Hemsl] A.Gray) for tropical animal production. Lives Res Rural Dev 17 (9): 100.

Malaka R. 1997. Effect of curdlan, a bacteria polysaccharide on the physical properties and microstructure of acid milk curd by lactic acid fermenation. [Thesis]. Miyazaki University, Japan.

Malaka R, Laga R. 2005. Isolasi dan identifikasi Lactobacillus bulgaricus strain ropy dari yoghurt komersial. Sains dan Teknologi 5 (1): 50-58. [Indonesian]

Mirnawati, Djulardi A, Marlida Y. 2013. Improving the quality of palm ketnel cake through fermentation by Eupenicillium javanicum as poultry ration. Pak J Nutr 12 (12): 1085-1088. DOI: 10.14334/wartazoa.v28i3.1820.

Mittal A, Singh G, Goyal F, Yadaf A, Aneja KR, Gautam SK, Agarwal NK. 2011. Isolation and biochemical characterisation of acidothermophilic extracellular phytase producing bacterial strain for potential application in poultry feed. J Microbiol 4: 273-282.

Mohamed R, Esmat A, Abou A, Gibriel AY, Rasmy N, Ferial M, Salem A. 2011. Effect of legume processing treatments individually or in combination on their phytic acid content. Afr J Food Sci Technol 2 (2): $36-46$

Oluwasola TA, Dairo FAS. 2016. Proximate composition, amino acid profile and some anti-nutrients of Tithonia diversifolia cut at two different times. Afr J Agric Res 11 (38): 3659-63. DOI: 10.5897/AJAR2016.10910.

Park WY, Matsui T, Konishi C, Kim SW, Yano F. 1999. Formaldehyde treatment suppresses ruminal degradation of phytate in soyabean meal and rapeseed meal. $\mathrm{Br} J$ Nutr 81 (6): 467-471. DOI $10.1017 / \mathrm{S} 0007114599000823$.

Pazla R. 2018. Pemanfaatan Pelepah Sawit dan Tithonia (Tithonia diversifolia) dalam Ransum Kambing Peranakan Etawa untuk Menunjang Program Swasembada Susu 2020. [Dissertation]. Andalas University, Padang. [Indonesian]

Pazla R, Jamarun N, Agustin F, Zain M, Arief, Oktiacahyani N. 2020. Effects of supplementation with phosphorus, calcium and manganese during oil palm frond fermentation by Phanerochaete chrysosporium on ligninase enzyme activity. Biodiversitas 21 (5): 1833-1838. DOI: 10.13057/biodiv/d210509.

Pazla R, Adrizal, Sriagtula R. 2021a. Intake, nutrient digestibility and production performance of Pesisir cattle fed Tithonia diversifolia and Calliandra calothyrsus-based rations with different protein and energy ratios. Adv Anim Vet Sci 9 (10): 1608-1615. DOI: 10.5713/ajas.17.0759.

Pazla R, Jamarun N, Zain M, Yanti G, Chandra RH. 2021b. Quality evaluation of tithonia (Tithonia diversifolia) with fermentation using Lactobacillus plantarum and Aspergillus ficuum at different incubation times. Biodiversitas 22 (9): 3936-3942. DOI: $10.13057 /$ biodiv/d220940.

Pazla R, Zain M, Ryanto I, Dona A. 2018. Supplementation of minerals (phosphorus and sulfur) and Saccharomyces cerevisiae in a sheep diet based on a cocoa by-product. Pak J Nutr 17 (7): 329-335. DOI: 10.3923/pjn.2018.329.335.

Poernomo AT, Isnaeni, Sugianto, Purwanto DA, Dewi AC, Suryagama D. 2017. Pengaruh nutrisi pada produksi dan karakterisasi protease dari bakteri termofilik isolat LS-1 lumpur sidoarjo. Jurnal farmasi dan Ilmu Kefarmasian Indonesia 4 (2): 52-59. DOI: 10.20473/jfiki.v4i22017.51-58. [Indonesian]

Putra AYT, Rosida, Khoirul A. 2019. Chemical and sensory characteristic of sorghum (Sorghum bicolor) tapai with traditional packaging. Food Sci Technol J 1 (2): 92-99. DOI: 10.33512/fsj.v1i2.7096.

Reddy NR, Pierson MD. 1994. Reduction in Anti-nutritional and toxic components in plant foods (A) by fermentation. Food Res Intl 27 (3): 281-290. DOI: 10.1186/s43014-020-0020-5.

Selle PH, Ravindran V, Caldwell RA, Bryden WL. 2021. Phytate and phytase: consequences for protein utilisation. Nutr Res Rev 13 (2): 255-278. DOI: DOI: 10.1079/095442200108729098.

Selle PH, Ravindran V. 2007. Microbial phytase in poultry nutrition. Anim Feed Sci Technol 135 (1): 41. DOI: 10.1016/j.anifeedsci.2006.06.010.

Selle PH, Cowieson AJ, Ravindran V. 2009. Consequences of calcium interactions with phytate and phytase for poultry and pigs. Livest Sci 124 (1-3): 126-141. DOI: 10.1016/j.livsci.2009.01.006.

Sneath PHA, Mair NS, Sharpe ME, Holt JG. 1986. Bergey's Manual of Systematic Bacteriology. 2nd ed. Williams and Wilkins, Baltimore.

Sripo K, Phianmongkhol A, Wirjantoro TI. 2016. Effect of inoculum levels and final ph values on the antioxidant properties of black glutinous rice solution fermented by Lactobacillus bulgaricus. Intl Food Res J 23 (5): 2207-2213.

Susanti ER. 2012. Degradasi Asam Fitat pada Kambing Peranakan Etawah Laktasi yang Mendapat Ransum Bersuplemen Kedelai Sangrai, Vitamin dan Mineral. [Thesis]. Bogor Agricultural Institute, Bogor. [Indonesian]

Turk M. 1990. Cereal and Microbial Phytase, Phytase Degradation, Mineral Binding and Absorption. [Dissertation]. Chalmers University of Technology, Swedia. 